\title{
Pembinaan Kepada Pengurus Di Ponpes Mukhtar Syafa'at Blokagung Tegalsari Banyuwangi Tentang Kepemimpinan Dalam Islam Menurut Al-Qur'an Dan Hadist
}

\author{
Mahmudah1, Muhammad Imam Khaudli2 \\ IAI Darussalam Blokagung Banyuwangi \\ Email : ${ }^{1}$ mahmudah.iaida@gmail.com, ${ }^{2}$ Imamkhaudli13@gmail.com
}

\begin{abstract}
Leaders and leadership are daily problems in the life of society, organization, business, nation and state. The progress and setbacks of society, organization, business, nation and state are influenced by their leaders in social life, organization, business, nation and state. This service aims to explain the basis and foundation of Islamic leadership in the Qur'an and Hadith to the administrators of the Mukhtar Syafa'at Islamic Boarding School Blokagung Banyuwangi. The essence of this service is that a leader must serve the people he leads with love and sincerity as well as the pesantren administrators who devote themselves to the pesantren to carry out the task of advancing the pesantren and applying the knowledge that has been obtained to be applied to the younger students under level with full trust, fairness, and responsibility because every action will definitely be held accountable before Allah SWT.
\end{abstract}

Keywords: Leaders, Mukhtar Syafa'at Islamic Boarding School, Santri Management

\section{Pendahuluan}

Setiap kita memiliki kapasitas untuk menjadi pemimpin. ada sebuah jenis kepemimpinan yang disebut dengan Q Leader. ${ }^{1}$ Kepemimpinan Q dalam hal ini memiliki empat makna. Pertama, Q berarti kecerdasan atau intelligence, misalnya IQ (Kecerdasan Intelektual), EQ (Kecerdasan Emosional), dan SQ (Kecerdasan Spiritual). Q Leader berarti seorang pemimpin yang memiliki kecerdasan IQ-EQ-SQ yang cukup tinggi. Kedua, Q Leader berarti kepemimpinan yang memiliki quality, baik dari aspek visioner maupun aspek manajerial.

1 Aribowo Prijosaksono dan Roy Sembel, 2002. Kepemimpinan yang Melayani. http://www.sinarharapan.co.id

Pembinaan Kepada Pengurus Di Ponpes Mukhtar Syafa'at Blokagung Tegalsari Banyuwangi Tentang Kepemimpinan Dalam Islam Menurut Al-Qur'an Dan Hadist

Mahmudah, Muhammad Imam Khaudli 
Pemimpin dan kepemimpinan merupakan persoalan keseharian dalam kehidupan bermasyarakat, berorganisasi, berusaha, berbangsa dan bernegara. Kemajuan dan kemunduran masyarakat, organisasi, usaha, bangsa dan negara antara lain dipengaruhi oleh para pemimpinnya. Oleh karena itu sejumlah teori tentang pemimpin dan kepemimpinanpun bermunculan dan semakin berkembang.

Islam sebagai rahmat bagi seluruh manusia, telah meletakkan persoalan pemimpin dan kepemimpinan sebagai salah satu persoalan pokok dalam ajarannya. Beberapa pedoman atau panduan telah digariskan untuk melahirkan kepemimpinan yang diridai Allah SWT, yang membawa kemaslahatan, menyelamatkan manusia di dunia dan akhirat kelak.

Sejarah Islam telah membuktikan pentingnya masalah kepemimpinan ini setelah wafatnya Baginda Rasul. Para sahabat telah memberi penekanan dan keutamaan dalam melantik pengganti beliau dalam memimpin umat Islam. Umat Islam tidak seharusnya dibiarkan tanpa pemimpin. Sayyidina Umar R.A pernah berkata, “Tiada Islam tanpa jamaah, tiada jamaah tanpa kepemimpinan dan tiada kepemimpinan tanpa taat".

Pentingnya pemimpin dan kepemimpinan ini perlu dipahami dan dihayati oleh setiap umat Islam di negeri yang mayoritas warganya beragama Islam ini, meskipun Indonesia bukanlah negara Islam. Mukhtar Syafa'at merupakan Pondok Pesantren yang terletak di Dusun Blokagung Desa Karangdoro Kecamatan Tegalsari Kabupaten Banyuwangi yang terdiri dari pendidikan formal dan non formal. Pondok Pesantren Mukhtar Syafa'at setelah sepeninggalan Almarhum Kyai Ahmad Qusyairi yang merupakan putra dari Kyai Mukhtar Syafa'at Abdul Ghofur Pendiri Pondok Pesantren Darussalam, kepemimpinan pesantren diteruskan oleh istri dan putra-putra almarhum.

Tujuan dari pengabdian ini adalah untuk menjelaskan dasar dan landasan kepemimpinan islam dalam Al-Qur'an dan Hadist kepada para pengurus pesantren yang sedang menjalankan tugas dalam mengamalkan 
ilmu yang telah didapatkan di pesatren untuk diamalkan di pesantren. Sehingga pengajaran dan pengenalan lebih dini tentang kepemimpinan dalam Islam yang berlandaskan Al-Qur'an dan Hadits sangat penting untuk diterapkap khususnya oleh santri yang bertugas sebagai pengurus dalam menjalankan tugas sebagai seorang pemimpin.

\section{Metode}

Metode yang dipakai dalam program pengabdian ini menggunakan metode partisipatori action research untuk mengetahui permasalahan yang dihadapi para pengurus dalam menjalankan kegiatan di pesantren Mukhtar Syafa'at dan memberikan pembinaan terkait dasar bagi seorang pemimpin menurut Al-Qur'an dan Hadits.

Waktu dan Tempat

Hari/tanggal : Kamis, 25 Maret 2021

Waktu $\quad: 13.00-15.30$ WIB

Tempat : Pondok Pesantren Mukhtar Syafa'at Blokagung Karangdoro Tegalsari Kabupaten Banyuwangi

Peserta : Santri Putri dan masyarakat sekitar Pondok Pesantren Mukhtar Syafa'at Blokagung

\section{Hasil dan Diskusi}

\section{Tugas Pemimpin}

Pada prinsipnya menurut Islam setiap orang adalah pemimpin. Ini sejalan dengan fungsi dan peran manusia di muka bumi sebagai khalifahtullah, yang diberi tugas untuk senantiasa mengabdi dan beribadah kepada-Nya

"Kami telah menjadikan mereka itu sebagai pemimpin-pemimpin yang memberi petunjuk dengan perintah Kami dan telah Kami wahyukan kepada mereka mengerjakan kebajikan, mendirikan sembahyang, menunaikan zakat, dan hanya kepada Kamilah mereka selalu menyembah". (Al-Anbiya': 73) 
"Dan Kami jadikan di antara mereka itu pemimpin-pemimpin yang memberi petunjuk dengan perintah Kami ketika mereka sabar. Dan adalah mereka meyakini ayat-ayat Kami". (As-Sajdah: 24)

"Wahai orang-orang yang beriman, jadilah kamu orang yang benar-benar menegakkan keadilan, menjadi saksi karena Allah biarpun terhadap dirimu sendiri atau bapak ibu dan kaum kerabatmu. Jika ia kaya atau miskin, Allah lebih mengetahui kemaslahatan keduanya". (Qs. An-Nisa; 4: 135)

"Hai orang-orang yang beriman! Tegakkanlah keadilan sebagai saksi karena Allah. Dan janganlah rasa benci mendorong kamu berlaku tidak adil. Berlaku adillah, karena itu lebih dekat dengan taqwa..." (Q.s. Al-Maidah 5: 8)

"Sesungguhnya Allah menyuruh kamu menyampaikan amanat kepada yang berhak menerimanya, dan (menyuruh kamu) apabila menetapkan hukum di antara manusia supaya kamu menetapkan dengan adil. Sesungguhnya Allah memberi pengajaran yang sebaik-baiknya kepadamu. Sesungguhnya Allah adalah Maha Mendengar lagi Maha Melihat". (An-Nisa': 58)

"Hai Daud, sesungguhnya Kami menjadikan kamu khalifah (penguasa) di muka bumi, maka berilah keputusan (perkara) di antara manusia dengan adil dan janganlah kamu mengikuti hawa nafsu, karena ia akan menyesatkan kamu dari jalan Allah SWT. Sesungguhnya orang-orang yang sesat dari jalan Allah SWT akan mendapat azab yang berat, karena mereka melupakan hari perhitungan." (Qs Shad: 26)

Dalam sebuah kesempatan, ketika seorang perempuan dari suku Makhzun dipotong tangannya lantaran mencuri, kemudian keluarga perempuan itu meminta Usama bin Zaid supaya memohon kepada Rasulullah untuk membebaskannya, Rasulullah pun marah. Beliau bahkan mengingatkan bahwa, kehancuran masyarakat sebelum kita disebabkan oleh ketidakadilan dalam supremasi hukum seperti itu.

Dari Aisyah ra. bahwasanya Rasulullah saw. bersabda: adakah patut engkau memintakan kebebasan dari satu hukuman dari beberapa hukuman (yang diwajibkan) oleh Allah? Kemudian ia berdiri lalu berkhutbah, dan berkata: 'Hai para manusia! Sesungguhnya orang-orang sebelum kamu itu rusak/binasa dikarenakan apabila orang-orang yang mulia diantara mereka mencuri, mereka bebaskan. Tetapi, apabila orang yang lemah mencuri, 
mereka berikan kepadanya hukum'. (HR. Bukhari, Muslim, Tirmidzi, Nasa'i, Abu Daud, Ahmad, Dariini, dan Ibnu Majah)

\section{Memilih Pemimpin}

Pemimpin negara adalah faktor penting dalam kehidupan bernegara. Jika pemimpin negara itu jujur, baik, cerdas dan amanah, niscaya rakyatnya akan makmur. Sebaliknya jika pemimpinnya tidak jujur, korup, serta menzalimi rakyatnya, niscaya rakyatnya akan sengsara.

Oleh karena itulah Islam memberikan pedoman dalam memilih pemimpin yang baik. Dalam Al Qur'an, Allah SWT memerintahkan ummat Islam untuk memilih pemimpin yang baik dan beriman:

"Hai orang-orang yang beriman, janganlah kamu mengambil musuh-Ku dan musuhmu menjadi teman-teman setia yang kamu sampaikan kepada mereka (berita-berita Muhammad), karena rasa kasih sayang; padahal sesungguhnya mereka telah ingkar kepada kebenaran yang datang kepadamu, mereka mengusir Rasul dan (mengusir) kamu karena kamu beriman kepada Allah, Tuhanmu. Jika kamu benar-benar keluar untuk berjihad di jalan-Ku dan mencari keridhaan-Ku (janganlah kamu berbuat demikian). Kamu memberitahukan secara rahasia (berita-berita Muhammad) kepada mereka, karena rasa kasih sayang. Aku lebih mengetahui apa yang kamu sembunyikan dan apa yang kamu nyatakan. Dan barangsiapa di antara kamu yang melakukannya, maka sesungguhnya dia telah TERSESAT dari jalan yang lurus."(QS. 60. Al-Mumtahanah : 1)

"Hai orang2 yang beriman! Janganlah kamu jadikan bapak-bapak dan saudara-saudaramu menjadi pemimpin-pemimpinmu, jika mereka lebih mengutamakan kekafiran atas keimanan. Dan siapa di antara kamu menjadikan mereka menjadi pemimpin, maka mereka itulah orang2 yang zalim" (At Taubah:23)

"Hai orang2 yang beriman! Janganlah kamu mengambil orang2 kafir menjadi wali (teman atau pelindung)" (An Nisaa:144)

"Janganlah orang2 mukmin mengambil orang2 kafir jadi pemimpin, bukan orang mukmin. Barang siapa berbuat demikian, bukanlah dia dari (agama) Allah sedikitpun..." (Ali Imran:28) 
"Hai orang-orang yang beriman, janganlah kamu mengambil jadi pemimpinmu, orang-orang yang membuat agamamu jadi buah ejekan dan permainan, (yaitu) di antara orang-orang yang telah diberi Kitab sebelummu, dan orang-orang yang kafir (orang-orang musyrik). Dan bertakwalah kepada Allah jika kamu betul-betul orang-orang yang beriman". (Al-Maidah: 57)

"Hai orang-orang yang beriman, janganlah kamu mengambil orang-orang Yahudi dan Nasrani menjadi pemimpin-pemimmpin(mu): sebahagian mereka adalah pemimpin bagi sebahagian yang lain. Barangsiapa diantara kamu mengambil mereka sebagai pemimpin, maka sesungguhnya orang itu termasuk golongan mereka. Sesungguhnya Allah tidak memberi petunjuk kepada oarngorang yang zalim " (QS. Al-Maidah: 51)

\section{Akibat}

"Dan mereka berkata: "Ya Tuhan kami, sesungguhnya kami telah menta'ati pemimpin-pemimpin dan pembesar-pembesar kami, lalu mereka menyesatkan kami dari jalan (yang benar)". (al-Ahzab: 67)

"Hai orang-orang yang beriman, jika kamu MENTAATI orang-orang yang KAFIR itu, niscaya mereka mengembalikan kamu ke belakang (kepada kekafiran), lalu jadilah kamu orang-orang yang rugi. Tetapi (ikutilah Allah), Allah lah Pelindungmu, dan Dialah sebaik-baik Penolong."(QS.Ali 'Imraan :149150)

"Kabarkanlah kepada orang-orang MUNAFIQ bahwa mereka akan mendapat siksaan yang pedih. (yaitu) orang-orang yang mengambil orang-orang kafir menjadi teman-teman penolong dengan meninggalkan orang-orang mukmin. Apakah mereka mencari kekuatan di sisi orang kafir itu? Maka sesungguhnya semua kekuatan kepunyaan Allah."(QS. An-Nisaa' : 138-139)

"Kamu melihat kebanyakan dari mereka tolong-menolong dengan orang-orang yang kafir (musyrik). Sesungguhnya amat buruklah apa yang mereka sediakan untuk diri mereka, yaitu kemurkaan Allah kepada mereka; dan mereka akan kekal dalam siksaan. Sekiranya mereka beriman kepada Allah, kepada Nabi dan kepada apa yang diturunkan kepadanya (Nabi), niscaya mereka tidak akan mengambil orang-orang musyrikin itu menjadi penolong-penolong, tapi kebanyakan dari mereka adalah orang-orang yang FASIQ."(QS.Al-Maa-idah : 80-81)

Ketika Islam memberikan tanggungjawab berbeda, antara pria dan wanita tidak berarti Islam meninggikan yang satu dan merendahkan yang 
lain. Hak dan tanggung jawab itu sesungguhnya didasarkan oleh perbedaan fitrah manusia yang telah diciptakan oleh Allah secara berbeda pula. Allah dengan sifat al-Alim nya, tentulah lebih mengetahui apa yang baik dan bermanfaat bagi kemaslahatan manusia dibandingkan dengan manusia itu sendiri. Maka seorang muslim akan lebih percaya kepada faliditas informasi dari Allah dan Rasul-Nya ketimbang mempercayai perasaannya sendiri. ${ }^{2}$ sebagaimana Firman Allah dalam Surat An-Nisa': 34:

"Kaum laki-laki itu pemimpin bagi kaum perempuan, sebagaimana Allah telah melebhkannya atas kalian”. Rasulullah bersabda: “...Dan wanita adalah pemimpin atas rumah suaminya dan anak-anaknya, dan dia akan dimintai pertanggungjawaban atasnya" (HR. Bukhari dan Muslim).

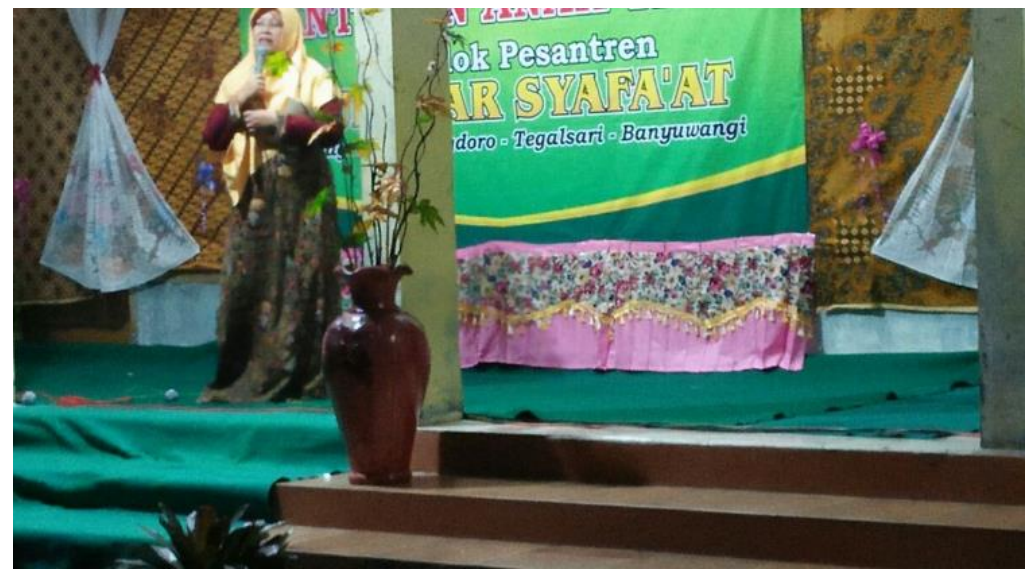

\section{Gambar 1. Pembinaan Pengurus Pondok Pesantren (Sumber: Dokumentasi Kegiatan, 2021)}

\section{Simpulan}

Pada prinsipnya menurut Islam setiap orang adalah pemimpin. Ini sejalan dengan fungsi dan peran manusia di muka bumi sebagai khalifahtullah, yang diberi tugas untuk senantiasa mengabdi dan beribadah kepada-Nya. Hakikat pemimpin dalam pandangan Islam adalah sebagai

${ }^{2}$ Djunaedi, Filosofi Dan Etika Kepemimpinan Dalam Islam, Jurnal Al-Mawarid Edisi XIII Tahun 2005, https://media.neliti.com/media/publications/26027-ID-filosofi-dan-etikakepemimpinan-dalam-islam.pdf 
khodimul ummah atau pelayan bagi rakyat yang dipimpinnya. Berpijak pada filosofi ini, maka seorang pemimpin harus melayani rakyat yang dipimpinnya dengan penuh rasa cinta dan keikhlasan begitu halnya para pengurus pesantren yang mengabdikan diri ke pesantren untuk menjalankan tugas memajukan pesantren dan mengamalkan ilmu pengetahuan yang telah didapatkan untuk diamalkan kepada adik-adik santri di bawah tingkatannya. Terkait dengan filosofi kepemimpinan tersebut, maka sesungguhnya sebuah kekuasaan dalam wujud apapun merupakan amanah yang harus dilaksanakan dengan sebaik-baiknya karena merupakan amanah dari Allah SWT yang suatu saat nanti akan dimintai pertanggungjawaban. Pentingnya penanaman moralitas dan etika dalam menjalankan sebuah amanah kekuasaan haruslah menjadi landasan yang kokoh agar tidak terjerumus pada penyalahgunaan wewenang kekuasaan tersebut dalam menjalankan peran sebagai pengurus di suatu lembaga pesatren khususnya di Pondok Pesantren Mukhtar Syafa'at Blokagung Banyuwangi.

\section{Referensi}

Aribowo Prijosaksono dan Roy Sembel. (2002). Kepemimpinan yang Melayani. http://www.sinarharapan.co.id

Departemen Agama RI. (1994) al-Qur'an dan Terjemahannya: Juz 1-30, Jakarta: PT. Kumudasmoro Grafindo Semarang.

Djunaedi. (2005). Filosofi Dan Etika Kepemimpinan Dalam Islam, Jurnal AlMawarid Edisi XIII Tahun 2005, https://media.neliti.com/media/publications/26027-ID-filosofi-danetika-kepemimpinan-dalam-islam.pdf 